\title{
Caffeine, coffee, and appetite control: a review
}

Matthew M. Schubert ${ }^{1}$, Christopher Irwin ${ }^{2}$, Rebekah F. Seay ${ }^{1}$, Holly E. Clarke ${ }^{1}$, Deanne Allegro ${ }^{1}$, and Ben Desbrow ${ }^{2}$.

$1=$ Department of Kinesiology

Auburn University at Montgomery

Montgomery, AL, USA

$2=$ School of Allied Health Sciences

Menzies Health Institute Queensland

Griffith University

Gold Coast, QLD, Australia

Corresponding author: Matthew M. Schubert, PhD

Department of Kinesiology

Auburn University at Montgomery

Montgomery, AL, USA

mschuber@aum.edu

Schubert and Allegro are assistant professors and Seay and Clarke are graduate students at Auburn University at Montgomery. Irwin is a senior lecturer and Desbrow is an associate professor at Griffith University. 


\section{Caffeine, coffee, and appetite control: a review}

Coffee and caffeine consumption has global popularity. However, evidence for the potential of these dietary constituents to influence energy intake, gut physiology, and appetite perceptions remains unclear. The purpose of this review was to examine the evidence regarding coffee and caffeine's influence on energy intake and appetite control. Literature was examined for studies that assessed the effects of caffeine and coffee on energy intake, gastric emptying, appetiterelated hormones, and perceptual measures of appetite. The literature review indicated that coffee administered 3-4.5 h before a meal had minimal influence on food and macronutrient intake, while caffeine ingested $0.5-4 \mathrm{~h}$ before a meal may suppress acute energy intake.

Evidence regarding the influence of caffeine and coffee on gastric emptying, appetite hormones, and appetite perceptions was equivocal. The influence of covariates such as genetics of caffeine metabolism and bitter taste phenotype remain unknown; longer controlled studies are needed.

Key words: coffee; caffeine; energy intake; appetite 


\section{Introduction}

Caffeine is the most widely consumed psychoactive substance in the world, with documented use dating back to the early Paleolithic period (Barone and Roberts 1996). For the majority of the population, coffee is the major vehicle for the delivery of caffeine, followed by tea and cola beverages (Mitchell et al. 2015; Mitchell et al. 2014). Given its popularity, there is interest in the effect of caffeine and caffeine-containing dietary products to influence population health.

Decreased physical activity and increased energy intake (largely exacerbated by the availability of inexpensive, nutrient-dense foods) has led to increasing weight gain with global obesity rates nearly doubling since 1980 (Ogden et al. 2014). Many weight-loss 'supplements' marketed to the general public include caffeine, often describing it as an 'appetite suppressant' and 'thermogenic aid'. There is some evidence to suggest these supplements can be effective for weight loss (Liu et al. 2013); however, these products often contain other ingredients, such as ephedrine, which makes an independent analysis on the effects of caffeine on weight loss difficult.

An additional concern is that caffeinated beverages can vary widely in both their caffeine (Desbrow et al. 2007; Ludwig et al. 2014) and energy content. For example, $250 \mathrm{ml}$ of instant coffee has $\sim 16 \mathrm{~kJ}$ of energy and $\sim 80 \mathrm{mg}$ of caffeine, while an equivalent serving of a cola beverage has $\sim 440 \mathrm{~kJ}$ of energy and $\sim 25 \mathrm{mg}$ of caffeine (Foodworks; Xyris Software, Australia). High calorie caffeinated beverages (e.g. carbonated soda beverages and energy drinks) are unanimously discouraged by health authorities due to their refined sugar content (U.S. Department of HHS and U.S. Department of Agriculture 2015-2020 Dietary Guidelines for Americans, available at http://health.gov/dietaryguidelines/2015/guidelines/). The caloric density of these products means they are less likely to contribute positively to healthy weight 
management. Finally, coffee and caffeinated beverages are often consumed in social environments and paired with meals or snacks, which can influence food choice and/or food liking (Collins, Freeman and Palmer 2012; Freeman, Collins and Palmer 2012).

It has been reported that dietary caffeine intake (Lopez-Garcia, van Dam, Rajpathak, et al. 2006) and coffee and tea consumption (Pan et al. 2013) have been associated with lower levels of long term weight gain in cohort studies. However, there are few studies that have examined if caffeinated coffee consumption reduces appetite and energy intake, and even they are contradictory in their results (Arciero et al. 1995; Astrup et al. 1990; Bracco et al. 1995; Dulloo et al. 1989; Gavrieli et al. 2011; Greenberg and Geliebter 2012). Additionally, it has been reported that caffeine and coffee may influence the rate of gastric emptying and secretion of gut hormones (Greenberg and Geliebter 2012; Johnston, Clifford and Morgan 2003), which play roles in appetite control (Horner et al. 2011; Horner et al. 2015).

To date, little attention has been given to whether caffeine and caffeinated beverages influence energy intake and appetite control. Therefore, the aim of this review was to provide an overview of how caffeine and coffee may influence energy intake and its determinants (perceptions of appetite, gastric emptying, and gut hormones). As long-term effects on these variables have not been examined in the literature, the current review focuses on acute effects. This information will clarify understanding of the role caffeinated beverages can play in energy regulation.

\section{Methods \\ Objectives}

The primary objectives of this review were to address the following questions: 
1) Does de/caffeinated coffee consumption influence acute $(\leq 24 \mathrm{~h})$ ad libitum energy intake or macronutrient composition in humans?

2) Does caffeine (anhydrous; pure) consumption influence acute $(\leq 24 \mathrm{~h})$ ad libitum energy intake or macronutrient composition in humans?

3) Does caffeine or de/caffeinated coffee influence acute gut physiology via changes in gastric emptying and secretion of gut hormones?

4) Does caffeine or de/caffeinated coffee influence perceptual measures of appetite? The secondary objective was to determine gaps in the literature and directions for future research.

Study eligibility

This systematic literature review was conducted in accordance with the Preferred

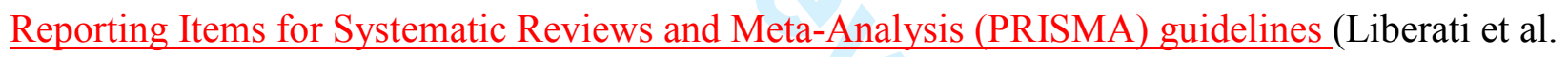
2009)._Journal articles, abstracts, and published dissertations or theses were eligible for inclusion in this review if they reported data for energy and/or macronutrient intake when a bolus of caffeine or coffee was administered before participants were offered food or began a period of observation. As such, studies were limited to acute trials generally conducted in a laboratory. Treatments permitted included caffeinated coffee (referred to henceforth as coffee) and caffeine (anhydrous/tablets). Studies needed to utilize a placebo (decaffeinated coffee or placebo tablets) or controlled (decaffeinated coffee or water) design. Studies on cola and sugar-sweetened beverages were excluded, generally because these studies (though utilizing similar design and outcome measures) have neglected to report or account for the caffeine content of beverages. Iced coffee beverages or milk-based coffee beverages were also excluded for this reason, 
although the literature search revealed no studies on these products. It has also been reported that fortifying cola beverages with caffeine requires an increase in sucrose content to maintain sweetness and counteract the bitterness of caffeine (Keast et al. 2011), which would confound results. Studies were included if they had been conducted in apparently healthy adult humans. Studies were deemed eligible using the PICOS approach (Liberati et al. 2009), and data on treatment and control conditions, participant characteristics, caffeine dose, beverage volume, and other outcome measures were recorded in an Excel spreadsheet (Microsoft Excel, Microsoft Corporation).

Sources of information and search strategy

Research databases (PubMed and Google Scholar) were initially searched independently by two authors in through September 2016 using an identical keyword search strategy.

Keywords utilized included the following combinations and searched the title, abstract, and keywords of each paper: coffee, caffeine, appetite, energy intake, gastric emptying, ghrelin, PYY, GLP-1. Titles and abstracts were examined initially and full papers were retrieved if studies met the inclusion criteria. A detailed search strategy is included as supplementary $\underline{\text { material. }}$

\section{Results}

General characteristics of studies and participants

Initial search results yielded a total of 4,087 unique results that were pared on the basis of title and abstract down to 50. In sum, 12 studies met inclusion criteria. Five studies identified assessed energy intake in response to coffee and caffeine. Another five studies identified 
assessed gastric emptying responses to coffee and caffeine, 4 studies examined gut hormone responses, and 5 reported measures of appetite perceptions. As studies were too few in each domain for meta-analyses, studies are summarized and their results presented as median and range. Table 1 summarizes all studies included in this review.

\section{Question 1 - coffee and energy intake}

Five studies assessed single meal ad libitum energy intake, a median of $3 \mathrm{~h}$ after treatment ingestion $(0.5-4 \mathrm{~h})$. Three of these studies utilized a test meal of varying macronutrient composition, thus providing data on macronutrient intake (Gavrieli, Karfopoulou, et al. 2013;

Gavrieli et al. 2011; Tremblay et al. 1988) while the remaining two studies provided single-item pasta meals (Belza, Toubro and Astrup 2009; Schubert et al. 2014). Two studies extended recording of energy and macronutrient intake for $24 \mathrm{~h}$ outside the lab using self-reported food records (Gavrieli, Karfopoulou, et al. 2013; Gavrieli et al. 2011). Three studies provided a meal concomitantly with treatment ingestion, with a median energy content of $594 \mathrm{~kJ}(594-1675 \mathrm{~kJ})$; the macronutrient composition of this meal was $62.5 \% \mathrm{CHO}(48-62.5 \%), 31 \%$ FAT (31-37 \%), and $6.5 \%$ PRO (6.5-15\%) (Gavrieli, Karfopoulou, et al. 2013; Gavrieli et al. 2011; Schubert et al. 2014). One study provided treatments in two boluses (4.5 and $2.5 \mathrm{~h}$ before lunch) (Schubert et al. 2014), while the other studies administered treatment in a single dose.

Median dose of caffeine administered in the coffee conditions was $262 \mathrm{mg}$ (192-526 mg). Median volume of coffee provided was $200 \mathrm{~mL}(200-450 \mathrm{~mL})$.

Results of single meal ad libitum energy and macronutrient intake are summarized in Table 2. Median energy intake with coffee consumption was $3144 \mathrm{~kJ}$ compared to $3164 \mathrm{~kJ}$ for the placebo or water control condition (three studies; 6 comparisons). For the two studies (5 
comparisons) (Gavrieli, Karfopoulou, et al. 2013; Gavrieli et al. 2011) that evaluated energy intake over the entire experimental day, median intake with coffee consumption was $9772 \mathrm{~kJ}$ $(8164-13500 \mathrm{~kJ})$ compared to $10011 \mathrm{~kJ}(9198-13800 \mathrm{~kJ})$ within the placebo or water control condition.

Single-meal macronutrient intake for carbohydrate was equivalent to a median of $85 \mathrm{~g}$ (72-251 g) with coffee consumption, compared to $80 \mathrm{~g}(73-260 \mathrm{~g})$ in the placebo/control

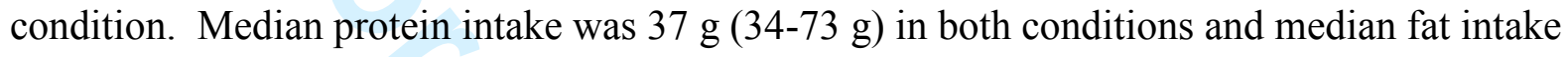
was $32 \mathrm{~g}$ (31-55 g) with coffee compared to $34 \mathrm{~g}$ (33-55 g) with placebo/control.

Daily macronutrient intake was equivalent to $250 \mathrm{~g}$ (198-399 g) carbohydrate, $84 \mathrm{~g}$ (71$128 \mathrm{~g})$ protein, and $99 \mathrm{~g}(78-115 \mathrm{~g})$ fat with coffee consumption. For the placebo/control condition, $255 \mathrm{~g}$ (234-426 g) of carbohydrate, $108 \mathrm{~g}(98-117 \mathrm{~g})$ of fat, and $99 \mathrm{~g}(90-124 \mathrm{~g})$ of protein were consumed.

Question 2 - Caffeine and energy intake

The three studies (four comparisons) (Belza, Toubro and Astrup 2009; Schubert et al. 2014; Tremblay et al. 1988) reporting energy intake after caffeine consumption yielded a median of $3017 \mathrm{~kJ}(2016-4708 \mathrm{~kJ})$ compared to $3446 \mathrm{~kJ}(2118-4859 \mathrm{~kJ})$ in the control condition. For macronutrient intake (one study, two comparisons) (Tremblay et al. 1988), a median of $125 \mathrm{~g}$ carbohydrate (103-146 g), $20 \mathrm{~g}$ (18-21 g) of protein, and $18 \mathrm{~g}(17-19 \mathrm{~g})$ of fat were consumed in the caffeine condition compared to $139 \mathrm{~g}$ (102-175 g) carbohydrate, $22 \mathrm{~g}$ (16-27 g) protein, and $23 \mathrm{~g}(17-28 \mathrm{~g})$ fat in the placebo condition.

The median caffeine dose administered in these conditions was $281 \mathrm{mg}$ (50-300 mg). Median volume of water provided with treatment in these studies was $313 \mathrm{~mL}(175-450 \mathrm{~mL})$. 
Question 3 - Caffeine, coffee, and gut physiology

Results of the 5 studies examining gastric emptying responses and 4 studies examining gut hormone responses are displayed in Table 3 (Akimoto et al. 2009; Beaudoin, Robinson and Graham 2011; Boekema et al. 2000; Franke et al. 2008; Gavrieli et al. 2011; Greenberg and Geliebter 2012; Lien et al. 1995; Schubert et al. 2014). For gastric emptying half-time in response to coffee ingestion, the median was 106 minutes for caffeine (36-179 minutes) compared to 122 minutes (45-182 minutes) for control. The only study using caffeine in this group reported that half-time for caffeine was 154 minutes compared to 182 minutes for the control condition.

Due to the various testing protocols, synthesis of the data for gut hormones was not considered possible. Instead, these data are summed according to the authors' conclusions in Table 3. Two studies (out of 3 measuring) reported increased GLP-1 concentrations in response to caffeinated and/or decaffeinated coffee (Beaudoin, Robinson and Graham 2011; Johnston, Clifford and Morgan 2003). Two studies that assess ghrelin responses reported no changes due to coffee, caffeine, or decaffeinated coffee; this was also observed with leptin levels (Gavrieli et al. 2011; Greenberg and Geliebter 2012). Finally, results for peptide YY were divergent, with one study reporting no treatment effects and another reporting increased concentrations only after decaffeinated coffee (Gavrieli et al. 2011; Greenberg and Geliebter 2012).

Question 4 - Caffeine, coffee, and appetite

Five studies reported results for appetite perceptions and these results are summed in Table 4 (Belza, Toubro and Astrup 2009; Gavrieli, Karfopoulou, et al. 2013; Gavrieli et al. 2011; 
Greenberg and Geliebter 2012; Schubert et al. 2014). As with gut hormones, synthesis was not possible as only 2 studies reported data for area under the concentration-time curve. Trends favoring caffeinated or decaffeinated coffee were observed in 3 studies (Gavrieli, Karfopoulou, et al. 2013; Greenberg and Geliebter 2012; Schubert et al. 2014). The studies that reported changes had larger volumes $(200-500 \mathrm{~mL})$ and caffeine doses $(250-526 \mathrm{mg})$ than the studies that did not observe alterations in appetite perceptions (Belza, Toubro and Astrup 2009; Gavrieli, Karfopoulou, et al. 2013; Gavrieli et al. 2011; Greenberg and Geliebter 2012; Schubert et al. 2014).

\section{Discussion}

Daily consumption of coffee is an extremely common behavior, yet its influence on energy and macronutrient intake and appetite regulation remains largely unknown. The results of this review indicate that coffee has no significant impact on single meal energy intake or macronutrient selection. However, there appears to be a small decrease $(-230 \mathrm{~kJ})$ in daily energy intake with coffee consumption. On the other hand, caffeine consumption may decrease single meal energy intake $(-430 \mathrm{~kJ})$, but there is no evidence regarding its influence on free-living daily energy intake. Additionally, there is no clear evidence to suggest caffeine alters gastric emptying, gut hormone secretion, or appetite perceptions in a manner that could influence energy intake.

Most of the studies examined varied both in dose of caffeine and coffee as well as volume of the treatment beverage. Caffeine doses varied considerably $(50-500+\mathrm{mg})$, with volume also varying between studies $(20-500 \mathrm{~mL})$. Due to the small number of studies and large discrepancies between them, no clear pattern of dose-response could be determined. It is worth 
noting that European coffees, particularly espresso, vary significantly in volume and caffeine content compared to American coffee; Italian espresso typically is $\sim 20 \mathrm{~mL}$ in volume with $\sim 104$ mg per serving of caffeine, while some of the beverages served at coffee shops in the United

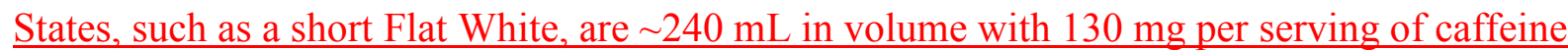
(Ludwig et al. 2014). These authors and others also have noted considerable variation in caffeine content of coffee purchased at coffee shops, suggesting that even when a standard protocol exists, variations are likely to occur (Desbrow, Henry and Scheelings 2012; Desbrow et al. 2007; Ludwig et al. 2014). It would be of interest in future studies to manipulate both the volume and $\underline{\text { caffeine content of administered beverages to examine their independent and combined effects }}$ on energy intake and appetite regulation.(Desbrow, Henry and Scheelings 2012; Desbrow et al. 2007; Ludwig et al. 2014)

Coffee consumption has been linked with numerous health benefits, including decreased mortality (Freedman et al. 2012; Lopez-Garcia et al. 2008), decreased risk of heart disease (Lopez-Garcia, van Dam, Willett, et al. 2006), lower levels of inflammation and endothelial dysfunction (Andersen et al. 2006; Lopez-Garcia, van Dam, Qi, et al. 2006), reduced incidence of diabetes (Ding et al. 2014; Huxley et al. 2009; van Dam and Hu 2005), decreased risk of some cancers (Floegel et al. 2012; Malerba et al. 2013; Wang et al. 2016), and improved mental health and well-being (Arab et al. 2011; Arab, Khan and Lam 2013; Ruusunen et al. 2010; van Gelder et al. 2007). However, the mechanisms needed to establish causation for many of these health benefits remain unclear. Additionally, coffee and caffeine consumption have been linked with less weight gain in data from cohort studies (Greenberg et al. 2005; Greenberg, Boozer and Geliebter 2006; Lopez-Garcia, van Dam, Rajpathak, et al. 2006; Pan et al. 2013). The results of the current review suggest the reasons for these associations remain to be elucidated. 
Despite the lack of evidence supporting (or refuting) coffee and caffeine's roles in body weight regulation, there are some potential mechanisms by which they may influence body weight. The thermic effect of caffeine is well-established (Hursel et al. 2011), and the increases in energy expenditure with caffeinated coffee consumption ( $430 \mathrm{~kJ}$ over $24 \mathrm{~h})$ (Hursel et al. 2011) may be adequate in some individuals for weight maintenance. Furthermore, evidence suggests coffee consumption may modify the gastrointestinal tract in such a way that lipid and glucose absorption are attenuated (Cha et al. 2012; Jaquet et al. 2009; Johnston, Clifford and Morgan 2003). It has recently been reported that consuming 4 cups of coffee per day before and during a 5-d high-fructose diet attenuated a diet-induced increase in hepatic insulin resistance; but this occurred without changes in body weight and despite the diet causing increased lipid deposition (Lecoultre et al. 2014). However, as coffee is a bioactive compound containing over 1000 ingredients, the precise mechanisms remain unknown. Caffeine, chlorogenic acids, and other biologically active compounds may all contribute to coffee's effect(s) on energy intake and eating behavior.

Most long-term research on caffeine and weight control has focused on combined supplements or use of caffeine in conjunction with a low calorie diet, and not caffeine alone. Thus, the data on controlled caffeine supplementation for weight control is minimal. Two shortterm studies evaluated the effect of controlled caffeine supplementation $(2 \times 2.5 \mathrm{mg} / \mathrm{kg}$ per day) over 4 days (Judice, Magalhaes, et al. 2013; Judice, Matias, et al. 2013) on energy expenditure and voluntary activity. Neither study reported changes in body weight over the observation period; however, both reported a non-significant decrease in energy intake of 460-880 kJ during the caffeine trials, which could have implications for body weight over the long term (Judice, Magalhaes, et al. 2013; Judice, Matias, et al. 2013). 
This review found insufficient evidence to determine coffee or caffeine's role in influencing appetite perceptions. However, caffeine has been implicated in appetite and feeding control in specific brain regions. Caffeine has been shown to decrease whole-brain cerebral blood flow and oxygen metabolism (Perthen et al. 2008; Vidyasagar et al. 2013; Wu et al. 2014), although this is dependent upon habituation to caffeine (Addicott et al. 2009; Kennedy and Haskell 2011). Caffeine has also been shown to influence neurotransmitter release via its inhibition of adenosine receptors, particularly the increased release of dopamine and serotonin (Fredholm et al. 1999). Increased dopamine and serotonin transmission could theoretically explain caffeine's influence on mood, which itself has been shown to influence energy intake and feeding behavior (Macht 2008; Mela 2006). The influence of caffeine or coffee on the neural responses to food cues therefore require further investigation to determine if central effects of these substances may influence feeding behavior and food choice, and how neurotransmitters such as dopamine and serotonin may contribute.

The relationship(s) between genetics and coffee and caffeine consumption also warrant further attention. To date, no study examining coffee/caffeine and appetite has accounted for genetic variation such as CYP1A2 genotype (the liver enzyme that metabolizes the majority of caffeine) or the PROP-6 taste receptor phenotype. For example, 'super-tasters' have a lower threshold for bitter taste, and may be more likely to avoid non-sweetened coffee (Ly and Drewnowski 2001).

The influence of additives in coffee (milk, sugar, non-nutritive sweetener, etc.) also deserves attention, but evidence is again lacking in the current literature. Since instant/black coffee is a beverage of minimal caloric value, adding milk or sugar increases the calorie content; the effect (if any) this would have on subsequent energy intake is unknown. Analysis of cohort 
data reported that additive use may explain some of the variation in body composition results among coffee consumers (Bouchard, Ross and Janssen 2010), but this area still requires further study. In addition, some observational evidence from Australian coffee shops highlighted the divergence of coffee products available to consumers, with those selecting a blended coffee (i.e. Frappuccino), requesting full cream milk, and purchasing the largest drink size were associated with increased energy consumption (Collins, Freeman and Palmer 2012; Freeman, Collins and Palmer 2012).

It has been reported that body composition can influence caffeine concentrations (Gavrieli, Fragopoulou, et al. 2013; Skinner et al. 2013), as well as modify glycemic and insulinaemic responses postprandially when a meal is co-ingested with caffeine (Gavrieli, Karfopoulou, et al. 2013). Only one of the studies in this review examined differences between lean and overweight/obese individuals (Gavrieli, Karfopoulou, et al. 2013). This study reported that appetite and energy intake were suppressed in obese individuals when they consumed 6 $\mathrm{mg} / \mathrm{kg}$ of caffeinated coffee, but not $3 \mathrm{mg} / \mathrm{kg}$ or at either dose in lean individuals (Gavrieli, Karfopoulou, et al. 2013). It is possible that this dose, and these individuals' larger fat mass, led to elevated caffeine concentrations (Skinner et al. 2013). Whether a threshold dose of caffeine and/or other coffee compounds is necessary to elicit changes in energy intake and appetite requires more study. An additional concern is that only one of the reviewed studies was conducted in obese individuals, with the remaining studies recruiting individuals with healthy BMIs; thus, future research needs to incorporate a participant group with a wider range of body compositions. This is important as it is well-known that obese individuals have different energy $\underline{\text { intake and appetite hormone responses compared to healthy controls, which suggests they may }}$ 
respond to coffee and caffeine intake differently than their lean counterparts (Brennan et al. 2012; Clamp et al. 2015).

Given the sparsity of research investigating the impact of coffee on appetite, it is pertinent to discuss recommendations for future studies. Controlled laboratory trials provide one option. Ideally, these studies should incorporate a pre-trial standardization and screening protocol, including phenotype and genotype screening, rigorous dietary and physical activity $\underline{\text { control procedures, and a supervised environment. Previous researchers have indicated that water }}$ with quinine can serve as an effective placebo (Hodgson, Randell and Jeukendrup 2013) to mimic coffee without complicating the design by using decaffeinated coffee, since decaf still $\underline{\text { contains active ingredients. It is paramount volume be standardized between conditions, unless }}$ $\underline{\text { this is the dependent variable of interest - in this case, care must be taken to match other }}$ variables and confounders such as caffeine intake and chlorogenic acid concentrations. If the

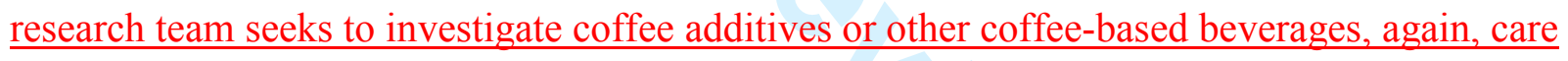
should be taken to match volume and caffeine levels so any "true" effects can be identified. $\underline{\text { Studies conducted in the lab are useful for examining the mechanisms related to coffee, caffeine, }}$ and appetite regulation, but results are not always applicable to real world settings. As an alternative to laboratory studies, researchers could consider a pragmatic investigation. Participants should still be screened for phenotype and genotype, as these variables would be included in analyses as covariates or subgroups. The pragmatic approach would allow researchers to enhance ecological validity. A protocol similar to recent work examining the influence of coffee on hydration status (Killer, Blannin and Jeukendrup 2014) could be employed. In this study, participants were provided enough coffee to consume $4 \mathrm{mg} \cdot \mathrm{kg}^{-}$ ${ }_{1}^{1}$ per day over 3 days and consumed their coffee as four $200 \mathrm{~mL}$ boluses each day. A study of 
$\underline{\text { this nature would provide more information on overall energy balance, physical activity, and }}$ eating behavior instead of mechanisms. Ideally, the study would last several months and utilize cutting edge technology to monitor energy balance, such as doubly-labeled water, multisensory activity monitors (i.e. ActiHeart or Sensewear Pro), food diaries, and calculation of energy intake from changes in body composition and total energy expenditure (Hall 2012). However, the $\underline{\text { logistics of such a study present challenges, such as should coffee and caffeine consumption }}$ outside of what is provided to participants be standardized, should the design be a parallel group or cross-over study, and how many participants would be appropriate.

A limitation of the present review is that all included studies utilized instant coffee or anhydrous caffeine compared to other forms of coffee or vehicles for caffeine consumption (i.e. colas, energy drinks, etc.). It is also likely that many individuals consume coffee with other components (i.e. milk, sugar). Additionally, we were only able to find one study assessing tea (green, oolong, or black) consumed as a beverage (Reinbach et al. 2009). Other studies examining tea extracts in capsule form or as part of a different beverage have been conducted but did not have tea-only beverage conditions and therefore were not eligible for this review (Belza, Toubro and Astrup 2009; Carter and Drewnowski 2012; Diepvens et al. 2007; Diepvens, Westerterp and Westerterp-Plantenga 2007; Gregersen et al. 2009; Hsu et al. 2008; Kovacs et al. 2004). Studies examining other forms of coffee (i.e. espresso, latte, etc.) were also lacking. The influence of these commonly consumed caffeinated beverages and beverage additives on energy and macronutrient intake deserves further attention. Finally, the characteristics of study designs (i.e. beverage volume, energy content of the beverages or test meals) complicated the ability to conduct more formal statistical analyses. 


\section{Conclusion}

The literature to date examining the effect of caffeine and coffee consumption on energy intake is limited, and therefore mostly equivocal. Thus, evidence is relatively scarce at present for how these dietary constituents influence appetite, gut physiology, and food intake. Based on this review, coffee appears to some promise as a means of altering appetite and energy intake, but whether this is due to the volume ingested or coffee's ingredients specifically needs to be elucidated. However, their influence(s) on energy and macronutrient intake over longer periods of time remains unknown. Further controlled, well-designed, and adequately powered cross-over trials are needed to determine the efficacy of caffeine and coffee to manipulate food intake, feeding behavior, and appetite. In addition, covariates such as genetics related to taste perception and caffeine metabolism provide novel areas of study to determine patterns of caffeine and coffee consumption and susceptibility to their potential effects. Neuro-imaging studies investigating the influence of caffeine and coffee consumption on appetite-regulating brain regions may also provide a novel means for examining the potential mechanisms of these compounds.

\section{Acknowledgements}

The authors thank Anna Gavrieli for sharing her data. No funding or sponsorship was received as part of preparing this review. The authors report no conflicts of interest, aside from the consumption of copious amounts of coffee and other caffeinated substances. 


\section{REFERENCES CITED}

Addicott MA, Yang LL, Peiffer AM, Burnett LR, Burdette JH, Chen MY, Hayasaka S, Kraft RA, Maldjian JA, Laurienti PJ. 2009. The effect of daily caffeine use on cerebral blood flow: How much caffeine can we tolerate? Human brain mapping. Oct;30:3102-3114. Epub 2009/02/17.

Akimoto K, Inamori M, Iida H, Endo H, Akiyama T, Ikeda T, Fujita K, Takahashi H, Yoneda M, Goto A, et al. 2009. Does postprandial coffee intake enhance gastric emptying?: a crossover study using continuous real time $13 \mathrm{C}$ breath test (BreathID system). Hepatogastroenterology. May-Jun;56:918-920.

Andersen LF, Jacobs DR, Jr., Carlsen MH, Blomhoff R. 2006. Consumption of coffee is associated with reduced risk of death attributed to inflammatory and cardiovascular diseases in the Iowa Women's Health Study. The American journal of clinical nutrition. May;83:1039-1046. Epub 2006/05/11.

Arab L, Biggs ML, O'Meara ES, Longstreth WT, Crane PK, Fitzpatrick AL. 2011. Gender differences in tea, coffee, and cognitive decline in the elderly: the Cardiovascular Health Study. Journal of Alzheimer's disease : JAD.27:553566.

Arab L, Khan F, Lam H. 2013. Epidemiologic evidence of a relationship between tea, coffee, or caffeine consumption and cognitive decline. Adv Nutr. Jan;4:115-122.

Arciero PJ, Gardner AW, Calles-Escandon J, Benowitz NL, Poehlman ET. 1995. Effects of caffeine ingestion on NE kinetics, fat oxidation, and energy expenditure in younger and older men. Am J Physiol. Jun;268:E1192-1198.

Astrup A, Toubro S, Cannon S, Hein P, Breum L, Madsen J. 1990. Caffeine: a double-blind, placebo-controlled study of its thermogenic, metabolic, and cardiovascular effects in healthy volunteers. Am J Clin Nutr. May;51:759767.

Barone JJ, Roberts HR. 1996. Caffeine consumption. Food Chem Toxicol. Jan;34:119-129.

Beaudoin MS, Robinson LE, Graham TE. 2011. An oral lipid challenge and acute intake of caffeinated coffee additively decrease glucose tolerance in healthy men. J Nutr. Apr 1;141:574-581.

Belza A, Toubro S, Astrup A. 2009. The effect of caffeine, green tea and tyrosine on thermogenesis and energy intake. Eur J Clin Nutr. Jan;63:57-64.

Boekema PJ, Lo B, Samsom M, Akkermans LM, Smout AJ. 2000. The effect of coffee on gastric emptying and orocaecal transit time. Eur J Clin Invest. Feb;30:129-134.

Bouchard DR, Ross R, Janssen I. 2010. Coffee, tea and their additives: association with BMI and waist circumference. Obesity facts. Dec;3:345-352. Epub 2011/01/05. 
Bracco D, Ferrarra JM, Arnaud MJ, Jequier E, Schutz Y. 1995. Effects of caffeine on energy metabolism, heart rate, and methylxanthine metabolism in lean and obese women. Am J Physiol. Oct;269:E671-678.

Brennan IM, Luscombe-Marsh ND, Seimon RV, Otto B, Horowitz M, Wishart JM, Feinle-Bisset C. 2012. Effects of fat, protein, and carbohydrate and protein load on appetite, plasma cholecystokinin, peptide YY, and ghrelin, and energy intake in lean and obese men. Am J Physiol Gastrointest Liver Physiol. Jul;303:G129-140.

Carter BE, Drewnowski A. 2012. Beverages containing soluble fiber, caffeine, and green tea catechins suppress hunger and lead to less energy consumption at the next meal. Appetite. 12//;59:755-761.

Cha KH, Song DG, Kim SM, Pan CH. 2012. Inhibition of gastrointestinal lipolysis by green tea, coffee, and gomchui (Ligularia fischeri) tea polyphenols during simulated digestion. Journal of agricultural and food chemistry. Jul 25;60:7152-7157.

Clamp L, Hehir AP, Lambert EV, Beglinger C, Goedecke JH. 2015. Lean and obese dietary phenotypes: differences in energy and substrate metabolism and appetite. Br J Nutr. Nov 28;114:1724-1733.

Collins A, Freeman J, Palmer M. Food and energy-dense beverage purchases at two major Australian cafes: purchasing behaviours and customer demographics. Nutrition \& Dietetics. Proceedings of the Dietitians Association of Australia 16th International Congress of Dietetics; 2012: Blackwell Publishing Asia.

Desbrow B, Henry M, Scheelings P. 2012. An examination of consumer exposure to caffeine from commercial coffee and coffee-flavoured milk. Journal of Food Composition and Analysis.28:114-118.

Desbrow B, Hughes R, Leveritt M, Scheelings P. 2007. An examination of consumer exposure to caffeine from retail coffee outlets. Food Chem Toxicol. Sep;45:1588-1592.

Diepvens K, Kovacs EMR, Nijs IMT, Vogels N, Westerterp-Plantenga MS. 2007. Effect of green tea on resting energy expenditure and substrate oxidation during weight loss in overweight females. British Journal of Nutrition.94:1026.

Diepvens K, Westerterp KR, Westerterp-Plantenga MS. 2007. Obesity and thermogenesis related to the consumption of caffeine, ephedrine, capsaicin, and green tea. Am J Physiol Regul Integr Comp Physiol. Jan;292:R77-85.

Ding M, Bhupathiraju SN, Chen M, van Dam RM, Hu FB. 2014. Caffeinated and Decaffeinated Coffee Consumption and Risk of Type 2 Diabetes: A Systematic Review and a Dose-Response Meta-analysis. Diabetes care. Feb;37:569-586.

Dulloo AG, Geissler CA, Horton T, Collins A, Miller DS. 1989. Normal caffeine consumption: influence on thermogenesis and daily energy expenditure in lean and postobese human volunteers. Am J Clin Nutr. Jan;49:44-50. 
Floegel A, Pischon T, Bergmann MM, Teucher B, Kaaks R, Boeing H. 2012. Coffee consumption and risk of chronic disease in the European Prospective Investigation into Cancer and Nutrition (EPIC)-Germany study. Am J Clin Nutr. Apr;95:901-908.

Franke A, Harder H, Orth AK, Zitzmann S, Singer MV. 2008. Postprandial walking but not consumption of alcoholic digestifs or espresso accelerates gastric emptying in healthy volunteers. J Gastrointestin Liver Dis. Mar;17:27-31.

Fredholm BB, Battig K, Holmen J, Nehlig A, Zvartau EE. 1999. Actions of caffeine in the brain with special reference to factors that contribute to its widespread use. Pharmacological reviews. Mar;51:83-133. Epub 1999/03/02.

Freedman ND, Park Y, Abnet CC, Hollenbeck AR, Sinha R. 2012. Association of coffee drinking with total and cause-specific mortality. The New England journal of medicine. May 17;366:1891-1904. Epub 2012/05/18.

Freeman J, Collins A, Palmer M. Nutrient content, customer demographics, and purchase behaviours of purchases at two major cafe chains in Australia. Nutrition \& Dietetics. Proceedings of the Dietitians Association of Australia 16th International Congress of Dietetics; 2012: Blackwell Publishing Asia.

Gavrieli A, Fragopoulou E, Mantzoros CS, Yannakoulia M. 2013. Gender and body mass index modify the effect of increasing amounts of caffeinated coffee on postprandial glucose and insulin concentrations; a randomized, controlled, clinical trial. Metabolism: clinical and experimental. Mar 13. Epub 2013/03/19.

Gavrieli A, Karfopoulou E, Kardatou E, Spyreli E, Fragopoulou E, Mantzoros CS, Yannakoulia M. 2013. Effect of different amounts of coffee on dietary intake and appetite of normal-weight and overweight/obese individuals. Obesity (Silver Spring). Jun;21:1127-1132.

Gavrieli A, Yannakoulia M, Fragopoulou E, Margaritopoulos D, Chamberland JP, Kaisari P, Kavouras SA, Mantzoros CS. 2011. Caffeinated coffee does not acutely affect energy intake, appetite, or inflammation but prevents serum cortisol concentrations from falling in healthy men. J Nutr. Apr 01;141:703-707.

Greenberg JA, Axen KV, Schnoll R, Boozer CN. 2005. Coffee, tea and diabetes: the role of weight loss and caffeine. Int J Obes (Lond). Sep;29:1121-1129.

Greenberg JA, Boozer CN, Geliebter A. 2006. Coffee, diabetes, and weight control. The American journal of clinical nutrition. Oct;84:682-693. Epub 2006/10/07.

Greenberg JA, Geliebter A. 2012. Coffee, hunger, and peptide YY. J Am Coll Nutr. Jun;31:160-166. 
Gregersen NT, Bitz C, Krog-Mikkelsen I, Hels O, Kovacs EM, Rycroft JA, Frandsen E, Mela DJ, Astrup A. 2009. Effect of moderate intakes of different tea catechins and caffeine on acute measures of energy metabolism under sedentary conditions. Br J Nutr. Oct;102:1187-1194.

Hall KD. 2012. Modeling metabolic adaptations and energy regulation in humans. Annu Rev Nutr. Aug 21;32:3554.

Hodgson AB, Randell RK, Jeukendrup AE. 2013. The metabolic and performance effects of caffeine compared to coffee during endurance exercise. PLoS One.8:e59561.

Horner KM, Byrne NM, Cleghorn GJ, Naslund E, King NA. 2011. The effects of weight loss strategies on gastric emptying and appetite control. Obes Rev. Nov;12:935-951.

Horner KM, Schubert MM, Desbrow B, Byrne NM, King NA. 2015. Acute exercise and gastric emptying: a metaanalysis and implications for appetite control. Sports Med. May;45:659-678.

Hsu CH, Tsai TH, Kao YH, Hwang KC, Tseng TY, Chou P. 2008. Effect of green tea extract on obese women: a randomized, double-blind, placebo-controlled clinical trial. Clin Nutr. Jun;27:363-370.

Hursel R, Viechtbauer W, Dulloo AG, Tremblay A, Tappy L, Rumpler W, Westerterp-Plantenga MS. 2011. The effects of catechin rich teas and caffeine on energy expenditure and fat oxidation: a meta-analysis. Obes Rev. Jul;12:e573-581.

Huxley R, Lee CM, Barzi F, Timmermeister L, Czernichow S, Perkovic V, Grobbee DE, Batty D, Woodward M. 2009. Coffee, decaffeinated coffee, and tea consumption in relation to incident type 2 diabetes mellitus: a systematic review with meta-analysis. Archives of internal medicine. Dec 14;169:2053-2063. Epub 2009/12/17.

Jaquet M, Rochat I, Moulin J, Cavin C, Bibiloni R. 2009. Impact of coffee consumption on the gut microbiota: a human volunteer study. Int J Food Microbiol. Mar 31;130:117-121.

Johnston KL, Clifford MN, Morgan LM. 2003. Coffee acutely modifies gastrointestinal hormone secretion and glucose tolerance in humans: glycemic effects of chlorogenic acid and caffeine. Am J Clin Nutr. Oct;78:728-733. Judice PB, Magalhaes JP, Santos DA, Matias CN, Carita AI, Armada-Da-Silva PA, Sardinha LB, Silva AM. 2013. A moderate dose of caffeine ingestion does not change energy expenditure but decreases sleep time in physically active males: a double-blind randomized controlled trial. Appl Physiol Nutr Metab. Jan;38:49-56.

Judice PB, Matias CN, Santos DA, Magalhaes JP, Hamilton MT, Sardinha LB, Silva AM. 2013. Caffeine intake, short bouts of physical activity, and energy expenditure: a double-blind randomized crossover trial. PLoS One.8:e68936. 
Keast RS, Sayompark D, Sacks G, Swinburn BA, Riddell LJ. 2011. The influence of caffeine on energy content of sugar-sweetened beverages: 'the caffeine-calorie effect'. Eur J Clin Nutr. Dec;65:1338-1344.

Kennedy DO, Haskell CF. 2011. Cerebral blood flow and behavioural effects of caffeine in habitual and nonhabitual consumers of caffeine: a near infrared spectroscopy study. Biological psychology. Mar;86:298-306. Epub 2011/01/26.

Killer SC, Blannin AK, Jeukendrup AE. 2014. No evidence of dehydration with moderate daily coffee intake: a counterbalanced cross-over study in a free-living population. PLoS One.9:e84154.

Kovacs EM, Lejeune MP, Nijs I, Westerterp-Plantenga MS. 2004. Effects of green tea on weight maintenance after body-weight loss. Br J Nutr. Mar;91:431-437.

Lecoultre V, Carrel G, Egli L, Binnert C, Boss A, MacMillan EL, Kreis R, Boesch C, Darimont C, Tappy L. 2014. Coffee consumption attenuates short-term fructose-induced liver insulin resistance in healthy men. Am J Clin Nutr. Feb;99:268-275.

Liberati A, Altman DG, Tetzlaff J, Mulrow C, Gotzsche PC, Ioannidis JP, Clarke M, Devereaux PJ, Kleijnen J, Moher D. 2009. The PRISMA statement for reporting systematic reviews and meta-analyses of studies that evaluate health care interventions: explanation and elaboration. PLoS Med. Jul 21;6:e1000100.

Lien HC, Chen GH, Chang CS, Kao CH, Wang SJ. 1995. The effect of coffee on gastric emptying. Nucl Med Commun. Nov;16:923-926.

Liu AG, Smith SR, Fujioka K, Greenway FL. 2013. The effect of leptin, caffeine/ephedrine, and their combination upon visceral fat mass and weight loss. Obesity (Silver Spring). Oct;21:1991-1996.

Lopez-Garcia E, van Dam RM, Li TY, Rodriguez-Artalejo F, Hu FB. 2008. The relationship of coffee consumption with mortality. Annals of internal medicine. Jun 17;148:904-914. Epub 2008/06/19.

Lopez-Garcia E, van Dam RM, Qi L, Hu FB. 2006. Coffee consumption and markers of inflammation and endothelial dysfunction in healthy and diabetic women. The American journal of clinical nutrition. Oct;84:888-893. Epub 2006/10/07.

Lopez-Garcia E, van Dam RM, Rajpathak S, Willett WC, Manson JE, Hu FB. 2006. Changes in caffeine intake and long-term weight change in men and women. Am J Clin Nutr. Mar;83:674-680.

Lopez-Garcia E, van Dam RM, Willett WC, Rimm EB, Manson JE, Stampfer MJ, Rexrode KM, Hu FB. 2006. Coffee consumption and coronary heart disease in men and women: a prospective cohort study. Circulation. May 2;113:2045-2053. 
Ludwig IA, Mena P, Calani L, Cid C, Del Rio D, Lean ME, Crozier A. 2014. Variations in caffeine and chlorogenic acid contents of coffees: what are we drinking? Food Funct. Aug;5:1718-1726.

Ly A, Drewnowski A. 2001. PROP (6-n-Propylthiouracil) tasting and sensory responses to caffeine,sucrose, neohesperidin dihydrochalcone and chocolate. Chemical senses. Jan;26:41-47.

Macht M. 2008. How emotions affect eating: a five-way model. Appetite. Jan;50:1-11.

Malerba S, Turati F, Galeone C, Pelucchi C, Verga F, La Vecchia C, Tavani A. 2013. A meta-analysis of prospective studies of coffee consumption and mortality for all causes, cancers and cardiovascular diseases. Eur J Epidemiol. Jul;28:527-539.

Mela DJ. 2006. Eating for pleasure or just wanting to eat? Reconsidering sensory hedonic responses as a driver of obesity. Appetite. Jul;47:10-17.

Mitchell DC, Hockenberry J, Teplansky R, Hartman TJ. 2015. Assessing dietary exposure to caffeine from beverages in the U.S. population using brand-specific versus category-specific caffeine values. Food Chem Toxicol. Jun;80:247-252.

Mitchell DC, Knight CA, Hockenberry J, Teplansky R, Hartman TJ. 2014. Beverage caffeine intakes in the U.S. Food Chem Toxicol. Jan;63:136-142.

Ogden CL, Carroll MD, Kit BK, Flegal KM. 2014. Prevalence of childhood and adult obesity in the United States, 2011-2012. JAMA. Feb 26;311:806-814.

Pan A, Malik VS, Hao T, Willett WC, Mozaffarian D, Hu FB. 2013. Changes in water and beverage intake and long-term weight changes: results from three prospective cohort studies. Int J Obes (Lond). Oct;37:1378-1385.

Perthen JE, Lansing AE, Liau J, Liu TT, Buxton RB. 2008. Caffeine-induced uncoupling of cerebral blood flow and oxygen metabolism: a calibrated BOLD fMRI study. Neuroimage. Mar 1;40:237-247.

Reinbach HC, Smeets A, Martinussen T, Møller P, Westerterp-Plantenga MS. 2009. Effects of capsaicin, green tea and $\mathrm{CH}-19$ sweet pepper on appetite and energy intake in humans in negative and positive energy balance. Clinical Nutrition. 6//;28:260-265.

Ruusunen A, Lehto SM, Tolmunen T, Mursu J, Kaplan GA, Voutilainen S. 2010. Coffee, tea and caffeine intake and the risk of severe depression in middle-aged Finnish men: the Kuopio Ischaemic Heart Disease Risk Factor Study. Public Health Nutr. Aug;13:1215-1220. 
Schubert MM, Grant G, Horner K, King N, Leveritt M, Sabapathy S, Desbrow B. 2014. Coffee for morning hunger pangs. An examination of coffee and caffeine on appetite, gastric emptying, and energy intake. Appetite.

Dec;83:317-326.

Skinner TL, Jenkins DG, Leveritt MD, McGorm A, Bolam KA, Coombes JS, Taaffe DR. 2013. Factors influencing serum caffeine concentrations following caffeine ingestion. J Sci Med Sport. Aug 6. Epub 2013/08/13.

Tremblay A, Masson E, Leduc S, Houde A, Despres JP. 1988. Caffeine reduces spontaneous energy intake in men but not women. Nutr Res.8:554-558.

van Dam RM, Hu FB. 2005. Coffee consumption and risk of type 2 diabetes: a systematic review. JAMA : the journal of the American Medical Association. Jul 6;294:97-104. Epub 2005/07/07.

van Gelder BM, Buijsse B, Tijhuis M, Kalmijn S, Giampaoli S, Nissinen A, Kromhout D. 2007. Coffee consumption is inversely associated with cognitive decline in elderly European men: the FINE Study. European journal of clinical nutrition. Feb;61:226-232.

Vidyasagar R, Greyling A, Draijer R, Corfield DR, Parkes LM. 2013. The effect of black tea and caffeine on regional cerebral blood flow measured with arterial spin labeling. Journal of cerebral blood flow and metabolism : official journal of the International Society of Cerebral Blood Flow and Metabolism. Jun;33:963-968. Epub 2013/03/15.

Wang A, Wang S, Zhu C, Huang H, Wu L, Wan X, Yang X, Zhang H, Miao R, He L, et al. 2016. Coffee and cancer risk: A meta-analysis of prospective observational studies. Sci Rep. Sep 26;6:33711.

Wu WC, Lien SH, Chang JH, Yang SC. 2014. Caffeine alters resting-state functional connectivity measured by blood oxygenation level-dependent MRI. NMR in biomedicine. Jan 30. Epub 2014/01/31. 
Table 1: Description of included studies

\begin{tabular}{|c|c|c|c|c|c|}
\hline Study & Participants & Caffeine Dose (mg) & $\begin{array}{l}\text { Administration } \\
\text { method }\end{array}$ & Assessments & Notes \\
\hline $\begin{array}{l}\text { Tremblay et al. (1988) } \\
\text { (caffeine) }\end{array}$ & $\begin{array}{l}10 \mathrm{M} \\
\text { BMI: } 22.8\end{array}$ & 300 & Capsule & EI & $\begin{array}{l}\text { Dose administered } 30 \text { min } \\
\text { before meal; habitual } \\
\text { caffeine consumption and } \\
\text { abstention not reported. }\end{array}$ \\
\hline $\begin{array}{l}\text { Tremblay et al. (1988) } \\
\text { (caffeine) }\end{array}$ & $\begin{array}{l}10 \mathrm{~F} \\
\text { BMI: } 19.9\end{array}$ & 300 & Capsule & EI & As above \\
\hline Lien et al. (1995) & $\begin{array}{l}93(56 \text { M } 37 \text { F) } \\
\text { BMI NR }\end{array}$ & $\begin{array}{l}\sim 100 \mathrm{mg} \text { ( } 4 \mathrm{~g} \text { instant } \\
\text { coffee })\end{array}$ & Coffee & GE & $\begin{array}{l}\text { GE assessed via } \\
\text { scintigraphy. } 500 \mathrm{~mL} \\
\text { bolus }+420 \mathrm{~kJ} \text { glucose. }\end{array}$ \\
\hline Boekema et al. (2000) & $\begin{array}{l}12 \mathrm{M} \\
\text { BMI NR }\end{array}$ & $180 \mathrm{mg}$ & Coffee & GE & $\begin{array}{l}\text { GE assessed via applied } \\
\text { potential tomography. } 280 \\
\text { mL bolus }+1675 \mathrm{~kJ} \text { test } \\
\text { meal. }\end{array}$ \\
\hline $\begin{array}{l}\text { Johnston, Clifford and } \\
\text { Morgan (2003) }\end{array}$ & $\begin{array}{l}9(4 \mathrm{M}, 5 \mathrm{~F}) \\
\text { BMI NR }\end{array}$ & NR & Coffee & $\mathrm{H}$ & $\begin{array}{l}\text { Glucose-dependent } \\
\text { insulinotropic polypeptide } \\
\text { (GIP) and glucagon-like } \\
\text { peptide-1(GLP-1) } \\
\text { measured. } 400 \mathrm{~mL} \text { bolus }+ \\
420 \mathrm{~kJ} \text { glucose. }\end{array}$ \\
\hline Franke et al. (2008) & $\begin{array}{l}10 \mathrm{M} \\
\text { BMI: } 23.8\end{array}$ & 300 mg (12 g Espresso) & Coffee & GE, A & $\begin{array}{l}\text { GE assessed via } \\
\text { ultrasound. } 2419 \mathrm{~kJ} \text { meal } \\
+40 \mathrm{~mL} \text { bolus. }\end{array}$ \\
\hline Akimoto et al. (2009) & $\begin{array}{l}6 \mathrm{M} \\
\text { BMI: } 21.5\end{array}$ & NR & Coffee & GE & $\begin{array}{l}\text { GE assessed via }{ }^{13} \mathrm{C} \\
\text { breath testing. } 19 \mathrm{~mL} \\
\text { bolus }+200 \mathrm{~mL} / 820 \mathrm{~kJ} \\
\text { test meal. }\end{array}$ \\
\hline $\begin{array}{l}\text { Belza, Toubro and } \\
\text { Astrup (2009) } \\
\text { (caffeine) }\end{array}$ & $\begin{array}{l}12 \mathrm{M} \\
\text { BMI: } 22.4\end{array}$ & 50 & Capsule & EI, A & $\begin{array}{l}\text { Dose administered } 4 \mathrm{~h} \\
\text { before meal w/ } 175 \mathrm{~mL} \\
\mathrm{H}_{2} \mathrm{O} \text {; habitual caffeine } \\
\text { consumption and } \\
\text { abstention not reported. }\end{array}$ \\
\hline $\begin{array}{l}\text { Beaudoin, Robinson and } \\
\text { Graham (2011) }\end{array}$ & $\begin{array}{l}11 \mathrm{M} \\
\text { BMI: } 24.7\end{array}$ & $5 \mathrm{mg} / \mathrm{kg}: 395$ & Coffee & $\mathrm{H}$ & $\begin{array}{l}\text { Given oral fat tolerance } \\
\text { test ( } 1 \mathrm{~g} / \mathrm{kg} \text { lipid, } 2940 \\
\mathrm{~kJ}) \text {; GIP, GLP-1 } \\
\text { measured. } 5 \text { h later, }\end{array}$ \\
\hline
\end{tabular}




\begin{tabular}{|c|c|c|c|c|c|}
\hline & & & & & $\begin{array}{l}\text { received coffee. At } 6 \mathrm{~h} \text {, } \\
\text { oral glucose tolerance test } \\
(1260 \mathrm{~kJ}) .\end{array}$ \\
\hline Gavrieli et al. (2011) & $\begin{array}{l}16 \mathrm{M} \\
\text { BMI: } 25.5\end{array}$ & $3 \mathrm{mg} / \mathrm{kg}: 247$ & Coffee & EI, H, A & $\begin{array}{l}200 \mathrm{~mL} \text { coffee with } 594 \\
\mathrm{~kJ} \text { breakfast; test meal } 3 \mathrm{~h} \\
\text { later } \\
\text { Ghrelin, PYY, GLP-1 } \\
\text { measured. }\end{array}$ \\
\hline $\begin{array}{l}\text { Greenberg and Geliebter } \\
\text { (2012) (coffee) }\end{array}$ & $\begin{array}{l}11 \mathrm{M} \\
\text { BMI: } 23.6\end{array}$ & $6 \mathrm{mg} / \mathrm{kg}: 423$ & Coffee & $\mathrm{H}, \mathrm{A}$ & $\begin{array}{l}-500 \mathrm{ml} \text { bolus, } 60 \mathrm{~min} \\
\text { rest, oral glucose tolerance } \\
\text { test with } 1260 \mathrm{~kJ} \text { glucose. }\end{array}$ \\
\hline $\begin{array}{l}\text { Greenberg and Geliebter } \\
\text { (2012) (caffeine) }\end{array}$ & As above & As above & In water & As above & As above \\
\hline $\begin{array}{l}\text { Gavrieli, Karfopoulou, } \\
\text { et al. (2013) (lean) }\end{array}$ & $\begin{array}{l}16(9 \mathrm{~F}) \\
\text { BMI: } 21.3\end{array}$ & $\begin{array}{l}3 \mathrm{mg} / \mathrm{kg}: 192 \\
6 \mathrm{mg} / \mathrm{kg}: 383\end{array}$ & Coffee & EI, A & $\begin{array}{l}200 \mathrm{~mL} \text { coffee with } 594 \\
\mathrm{~kJ} \text { breakfast; test meal } 3 \mathrm{~h} \\
\text { later }\end{array}$ \\
\hline $\begin{array}{l}\text { Gavrieli, Karfopoulou, } \\
\text { et al. (2013) } \\
\text { (overweight/obese) }\end{array}$ & $\begin{array}{l}17(8 \mathrm{~F}) \\
\text { BMI: } 30\end{array}$ & $\begin{array}{l}3 \mathrm{mg} / \mathrm{kg}: 263 \\
6 \mathrm{mg} / \mathrm{kg}: 526\end{array}$ & Coffee & As above & As above \\
\hline $\begin{array}{l}\text { Schubert et al. (2014) } \\
\text { (coffee) }\end{array}$ & $\begin{array}{l}12(9 \mathrm{~F}) \\
\text { BMI: } 22.7\end{array}$ & $\begin{array}{l}4 \mathrm{mg} / \mathrm{kg}+15 \mathrm{mg} \text { in } 450 \\
\mathrm{ml} \text { coffee: } 277\end{array}$ & $\begin{array}{l}\text { Capsules with decaf } \\
\text { coffee }\end{array}$ & $\mathrm{EI}, \mathrm{A}, \mathrm{GE}$ & $\begin{array}{l}225 \mathrm{~mL} \text { coffee with } 1675 \\
\mathrm{~kJ} \text { breakfast; } 225 \mathrm{~mL} \\
\text { coffee } 2 \mathrm{~h} \text { later; test meal } \\
2.5 \mathrm{~h} \text { after } 2^{\text {nd }} \text { coffee }(4.5 \\
\mathrm{h} \text { post-breakfast). GE } \\
\text { assessed via }{ }^{13} \mathrm{C} \text { breath } \\
\text { testing }\end{array}$ \\
\hline $\begin{array}{l}\text { Schubert et al. (2014) } \\
\text { (caffeine) }\end{array}$ & As above & 4 mg/kg: 262 & Capsules & EI, A, GE & $\begin{array}{l}\text { As above, but with } \mathrm{H}_{2} \mathrm{O} \\
\text { instead of coffee }\end{array}$ \\
\hline
\end{tabular}


Table 2: Results of included studies for single meal energy and macronutrient intake

\begin{tabular}{|c|c|c|c|c|c|}
\hline Study & Treatment EI & $\begin{array}{l}\text { Control/Placebo } \\
\text { EI }\end{array}$ & CHO Intake & Fat Intake & Protein Intake \\
\hline $\begin{array}{l}\text { Tremblay et al. } \\
\text { (1988) } \\
\text { (caffeine - men) }\end{array}$ & $3416 \pm 925 \mathrm{~kJ} *$ & $4367 \pm 875 \mathrm{~kJ}$ & $\begin{array}{l}\text { Treatment: } 146 \pm 39 \mathrm{~g} \\
(72 \pm 19 \%) \\
\text { Control: } 175 \pm 38 \mathrm{~g} \\
(67 \pm 15 \%)\end{array}$ & $\begin{array}{l}\text { Treatment: } 19 \pm 9 \mathrm{~g} * \\
(21 \pm 10 \%) \\
\text { Control: } 28 \pm 10 \mathrm{~g} \\
(24 \pm 9 \%)\end{array}$ & $\begin{array}{l}\text { Treatment: } 21 \pm 7 \mathrm{~g} \\
\begin{array}{l}(10 \pm 3 \%) \\
\text { Control: } 27 \pm 7 \mathrm{~g} \\
(10 \pm 3 \%)\end{array}\end{array}$ \\
\hline $\begin{array}{l}\text { Tremblay et al. } \\
(1988) \\
\text { (caffeine - women) }\end{array}$ & $2617 \pm 871 \mathrm{~kJ}$ & $2525 \pm 858 \mathrm{~kJ}$ & $\begin{array}{l}\text { Treatment: } 103 \pm 29 \mathrm{~g} \\
\begin{array}{l}(66 \pm 19 \%) \\
\text { Control: } 102 \pm 42 \mathrm{~g} \\
(68 \pm 28 \%)\end{array}\end{array}$ & $\begin{array}{l}\text { Treatment: } 17 \pm 11 \mathrm{~g} \\
(25 \pm 16 \%) \\
\text { Control: } 17 \pm 8 \mathrm{~g} \\
(25 \pm 12 \%)\end{array}$ & $\begin{array}{l}\text { Treatment: } 18 \pm 11 \mathrm{~g} \\
\begin{array}{l}(12 \pm 7 \%) \\
\text { Control: } 16 \pm 8 \mathrm{~g} \\
(11 \pm 5 \%)\end{array}\end{array}$ \\
\hline $\begin{array}{l}\text { Belza, Toubro and } \\
\text { Astrup (2009) } \\
\text { (caffeine) }\end{array}$ & $4708 \pm 1306 \mathrm{~kJ}$ & $4859 \pm 1493 \mathrm{~kJ}$ & $\mathrm{NM}$ & $\mathrm{NM}$ & $\mathrm{NM}$ \\
\hline $\begin{array}{l}\text { Gavrieli et al. } \\
\text { (2011)(coffee) }\end{array}$ & $7300 \pm 1700 \mathrm{~kJ}$ & $7300 \pm 1900 \mathrm{~kJ}$ & $\begin{array}{l}\text { Treatment: } 251 \pm 14 \mathrm{~g} \\
(58 \pm 3 \%) \\
\text { Control: } 260 \pm 15 \mathrm{~g} \\
(60 \pm 3 \%)\end{array}$ & $\begin{array}{l}\text { Treatment: } 55 \pm 4 \mathrm{~g} \\
(28 \pm 2 \%) \\
\text { Control: } 55 \pm 5 \mathrm{~g} \\
(28 \pm 3 \%)\end{array}$ & $\begin{array}{l}\text { Treatment: } 73 \pm 4 \mathrm{~g} \\
(17 \pm 1 \%) \\
\text { Control: } 73 \pm 5 \mathrm{~g} \\
(17 \pm 1 \%)\end{array}$ \\
\hline $\begin{array}{l}\text { Gavrieli, } \\
\text { Karfopoulou, et al. } \\
\text { (2013) (lean) } \\
\text { (3 mg/kg coffee) }\end{array}$ & $3031 \pm 1595 \mathrm{~kJ}$ & $3199 \pm 1072 \mathrm{~kJ}$ & $\begin{array}{l}\text { Treatment: } 73 \pm 44 \mathrm{~g} \\
(40 \pm 24 \%) \\
\text { Control: } 80 \pm 36 \mathrm{~g} \\
(42 \pm 19 \%)\end{array}$ & $\begin{array}{l}\text { Treatment: } 32 \pm 20 \mathrm{~g} \\
(40 \pm 25 \%) \\
\text { Control: } 33 \pm 10 \mathrm{~g} \\
(39 \pm 12 \%)\end{array}$ & $\begin{array}{l}\text { Treatment: } 34 \pm 17 \mathrm{~g} \\
(19 \pm 9 \%) \\
\text { Control: } 37 \pm 11 \mathrm{~g} \\
(19 \pm 6 \%)\end{array}$ \\
\hline $\begin{array}{l}\text { Gavrieli, } \\
\text { Karfopoulou, et al. } \\
(2013)(\text { lean }) \\
(6 \mathrm{mg} / \mathrm{kg} \text { coffee })\end{array}$ & $3257 \pm 1063 \mathrm{~kJ}$ & $3199 \pm 1072 \mathrm{~kJ}$ & $\begin{array}{l}\text { Treatment: } 85 \pm 39 \mathrm{~g} \\
(44 \pm 16 \%) \\
\text { Control: } 80 \pm 36 \mathrm{~g} \\
(42 \pm 19 \%)\end{array}$ & $\begin{array}{l}\text { Treatment: } 32 \pm 10 \mathrm{~g} \\
(37 \pm 12 \%) \\
\text { Control: } 33 \pm 10 \mathrm{~g} \\
(39 \pm 12 \%)\end{array}$ & $\begin{array}{l}\text { Treatment: } 37 \pm 10 \mathrm{~g} \\
(19 \pm 5 \%) \\
\text { Control: } 37 \pm 11 \mathrm{~g} \\
(19 \pm 6 \%)\end{array}$ \\
\hline $\begin{array}{l}\text { Gavrieli, } \\
\text { Karfopoulou, et al. } \\
\text { (2013) } \\
\text { (overweight/obese) } \\
\text { (3 mg/kg coffee) }\end{array}$ & $4103 \pm 1532 \mathrm{~kJ} *$ & $3128 \pm 1629 \mathrm{~kJ}$ & $\begin{array}{l}\text { Treatment: } 108 \pm 40 \mathrm{~g} \\
(44 \pm 16 \%) \\
\text { Control: } 73 \pm 40 \mathrm{~g} \\
(39 \pm 21 \%)\end{array}$ & $\begin{array}{l}\text { Treatment: } 41 \pm 16 \mathrm{~g} \\
(38 \pm 15 \%) \\
\text { Control: } 34 \pm 21 \mathrm{~g} \\
(41 \pm 25 \%)\end{array}$ & $\begin{array}{l}\text { Treatment: } 44 \pm 14 \mathrm{~g} \\
(18 \pm 6 \%) \\
\text { Control: } 37 \pm 19 \mathrm{~g} \\
(20 \pm 10 \%)\end{array}$ \\
\hline $\begin{array}{l}\text { Gavrieli, } \\
\text { Karfopoulou, et al. } \\
(2013)(\text { overweight/o } \\
\text { bese) }(6 \mathrm{mg} / \mathrm{kg} \\
\text { coffee) }\end{array}$ & $2927 \pm 1428 \mathrm{~kJ}$ & $3128 \pm 1629 \mathrm{~kJ}$ & $\begin{array}{l}\text { Treatment: } 72 \pm 48 \mathrm{~g} \\
\begin{array}{l}(41 \pm 28 \%) \\
\text { Control: } 73 \pm 40 \mathrm{~g} \\
\underline{(39 \pm 21 \%)}\end{array}\end{array}$ & $\begin{array}{l}\text { Treatment: } 31 \pm 17 \mathrm{~g} \\
(40 \pm 22 \%) \\
\text { Control: } 34 \pm 21 \mathrm{~g} \\
\underline{(41 \pm 25 \%)}\end{array}$ & $\begin{array}{l}\text { Treatment: } 34 \pm 17 \mathrm{~g} \\
(20 \pm 10 \%) \\
\text { Control: } 37 \pm 19 \mathrm{~g} \\
\underline{(20 \pm 10 \%)}\end{array}$ \\
\hline $\begin{array}{l}\text { Schubert et al. } \\
(2014)\end{array}$ & $2016 \pm 750 \mathrm{~kJ}$ & $2118 \pm 663 \mathrm{~kJ}$ & NM & NM & NM \\
\hline
\end{tabular}




\begin{tabular}{|c|c|c|c|c|c|}
\hline (coffee) & & & & & \\
\hline $\begin{array}{l}\text { Schubert et al. } \\
\text { (2014) (caffeine) }\end{array}$ & $2287 \pm 648 \mathrm{~kJ}$ & $2118 \pm 663 \mathrm{~kJ}$ & NM & NM & NM \\
\hline
\end{tabular}

Data are means \pm SDs (converted where applicable). $\mathrm{NM}=$ not measured $\mathrm{NA}=$ not applicable $\mathrm{EE}=$ energy expenditure

$\mathrm{EI}=$ Energy intake $*$ significant difference reported 
Table 3 Results of included studies for gastric emptying and gut hormones

\begin{tabular}{|c|c|c|}
\hline Study & Gastric emptying Half time & Gut Hormones \\
\hline Lien et al. (1995) & $\begin{array}{l}\text { Control condition: } 45.0 \pm 23.1 \mathrm{~min} \\
\text { Coffee condition: } 35.7 \pm 10.5 \mathrm{~min} *\end{array}$ & NA \\
\hline Boekema et al. (2000) & $\begin{array}{l}\text { Control condition: } 83.4 \text { min (median) } \\
\text { Coffee condition: } 75.7 \text { min (median) }\end{array}$ & NA \\
\hline Johnston, Clifford and Morgan (2003) & NA & $\begin{array}{l}\text { GIP AUC lower after caffeinated and decaffeinated } \\
\text { coffee } \\
\text { GLP AUC higher after decaffeinated coffee }\end{array}$ \\
\hline Franke et al. (2008) & $\begin{array}{l}\text { Control condition: } 123 \pm 5 \mathrm{~min} \\
\text { Coffee condition: } 125 \pm 9 \mathrm{~min}\end{array}$ & NA \\
\hline Akimoto et al. (2009) & $\begin{array}{l}\text { Control condition: } 121.5 \text { min (median) } \\
\text { Coffee condition: } 105.7 \text { min (median)* }\end{array}$ & NA \\
\hline Beaudoin, Robinson and Graham (2011) & NA $>1+2$ & $\begin{array}{l}\text { Increased GLP-lin caffeinated coffee and } \\
\text { decaffeinated coffee trials over OFTT and OGTT } \\
\text { control trials } \\
\text { Increase GIP only in OFTT/Caf trial }\end{array}$ \\
\hline Gavrieli, Karfopoulou, et al. (2013) & NA & $\begin{array}{l}\text { Ghrelin, PYY, and GLP-1 revealed no effect of } \\
\text { treatment during testing or for AUC }\end{array}$ \\
\hline Greenberg and Geliebter (2012) & NA & $\begin{array}{l}\text { Ghrelin and leptin revealed no effect of treatment } \\
\text { during testing or for AUC } \\
\text { PYY significantly elevated } 60-90 \text { after decaf coffee; } \\
\text { AUC higher than caffeine or control }\end{array}$ \\
\hline Schubert et al. (2014) & $\begin{array}{l}\text { Control condition: } 182 \pm 34 \mathrm{~min} \\
\text { Caffeine condition: } 154 \pm 18 \mathrm{~min} \\
\text { Decaf condition: } 177 \pm 25 \mathrm{~min} \\
\text { Coffee condition: } 179 \pm 61 \mathrm{~min}\end{array}$ & NA \\
\hline
\end{tabular}

Data are means \pm SDs unless noted. Half time represents the length of time for half of the test meal/beverage to empty from the stomach.

$\mathrm{NA}=$ not applicable $*$ = significant difference reported $\quad \mathrm{AUC}=$ Area under the concentration-time curve

OFTT $=$ oral fat tolerance test $\quad$ OGTT $=$ oral glucose tolerance test 
Table 4 Results for included studies assessing appetite perceptions

\begin{tabular}{|c|c|}
\hline Study & Appetite results \\
\hline Belza, Toubro and Astrup (2009) & $\begin{array}{l}\text { No differences for hunger, fullness, prospective food consumption, or } \\
\text { satiety between caffeine and placebo }\end{array}$ \\
\hline Gavrieli et al. (2011) & $\begin{array}{l}\text { Hunger, desire to eat, satiety did not differ over time; hunger at } 3 \text { hours } \\
\text { was lower in caffeinated coffee than decaf or control; incremental AUC } \\
\text { trended towards reduced desire to eat compared to control }\end{array}$ \\
\hline Gavrieli, Karfopoulou, et al. (2013) & $\begin{array}{l}\text { Only in overweight } / \text { obese participants, satiety was higher } 15 \text { and } 60 \\
\text { minutes post low dose }(3 \mathrm{mg} / \mathrm{kg}) \text { coffee and } 15 \text { min post high dose coffee } \\
(6 \mathrm{mg} / \mathrm{kg} \text { ) compared to water. No other appetite differences. }\end{array}$ \\
\hline Greenberg and Geliebter (2012) & $\begin{array}{l}\text { Hunger AUC lowest in decaffeinated coffee, followed by caffeinated } \\
\text { coffee. Decaf was significantly different from placebo; caffeinated coffee } \\
\text { and caffeine were not. }\end{array}$ \\
\hline Schubert et al. (2014) & $\begin{array}{l}\text { No effects on hunger. Main effects of trial observed for satiety, } \\
\text { prospective food consumption, and fullness; effects were in favor } \\
\text { increased satiety and fullness and decreased prospective food consumption } \\
\text { such that coffee }>\text { decaf }>\text { placebo }>\text { caffeine. Post-hoc comparisons were } \\
\text { non-significant. }\end{array}$ \\
\hline
\end{tabular}


1

2

3

4

5

6

7

8

9

10

11

12

13

14

15

16

17

18

19

20

21

22

23

24

25

26

27

28

29

30

31

32

33

34

35

36

37

38

39

40

41

42

43

44

45

46

47

48

49

50

51

52

53

54

55

56

57

58

59

60

\section{Supplemental material}

Search Strategy - PubMed (MEDLINE)

Filter: humans

1. Coffee

2. Caffeine

3. Appetite

4. Ghrelin

5. Peptide YY

6. PYY

7. Glucagon-like peptide 1

8. GLP-1

9. Energy intake

10. Gastric emptying

11.1 and 3 or 4 or 5 or 6 or 7 or 8 or 9 or 10 or 11 or 12

12. 2 and 3 or 4 or 5 or 6 or 7 or 8 or 9 or 10 or 11 or 12 